\title{
Laser photogrammetry improves size and demographic estimates for whale sharks
}

Christoph A Rohner, Anthony J Richardson, Clare EM Prebble, Andrea D Marshall, Michael B Bennett, Scarla J Weeks, Geremy Cliff, Sabine P Wintner, Simon J Pierce

Whale sharks Rhincodon typus are globally threatened, but a lack of biological and demographic information hampers an accurate assessment of their vulnerability to further decline or capacity to recover. We used laser photogrammetry at two aggregation sites to obtain more accurate size estimates of free-swimming whale sharks compared to visual estimates, allowing improved estimates of biological parameters. Individual whale sharks ranged from 432-917 cm total length ( $T L$ ) (mean $\pm S D=673 \pm 118.8 \mathrm{~cm}, \mathrm{~N}=122$ ) in southern Mozambique and from 420-990 cm TL (mean \pm SD $=641 \pm 133 \mathrm{~cm}, \mathrm{~N}=46$ ) in Tanzania. By combining measurements of stranded individuals with photogrammetry measurements of free-swimming sharks, we calculated length at $50 \%$ maturity for males in Mozambique at $916 \mathrm{~cm}$ TL. Repeat measurements of individual whale sharks measured over periods from 347-1068 days yielded implausible growth rates, suggesting that the growth increment over this period was not large enough to be detected using laser photogrammetry, and that the method is best applied to estimating growth rates over longer (decadal) time periods. The sex ratio of both populations was biased towards males (74\% in Mozambique, $89 \%$ in Tanzania), the majority of which were immature $(98 \%$ in Mozambique, 94\% in Tanzania). The population structure for these two aggregations was similar to most other documented whale shark aggregations around the world. Information on small $(<400 \mathrm{~cm}$ ) whale sharks, mature individuals, and females in this region is lacking, but necessary to inform conservation initiatives for this globally threatened species. 
2 Christoph A. Rohner ${ }^{1,2 *}$, Anthony J. Richardson ${ }^{2,3}$, Clare E. M. Prebble ${ }^{1}$, Andrea D. Marshall ${ }^{1,4}$,

3 Michael B. Bennett ${ }^{5}$, Scarla J. Weeks ${ }^{6}$, Geremy Cliff ${ }^{7,8}$, Sabine P. Winter ${ }^{7,8}$ and Simon J. Pierce ${ }^{1,4}$

4

51 Marine Megafauna Foundation, Praia do Tofo, Inhambane, Mozambique

$6 \quad 2$ CSIRO Oceans and Atmosphere Flagship, Brisbane Queensland 4102, Australia

73 Centre for Applications in Natural Resource Mathematics (CARM), School of Mathematics and

8 Physics, The University of Queensland, St Lucia Queensland 4072, Australia

94 Wild Me, Praia do Tofo, Inhambane, Mozambique

105 School of Biomedical Sciences, The University of Queensland, St Lucia Queensland 4072, Australia

116 Biophysical Oceanography Group, School of Geography, Planning and Environmental Management,

12 The University of Queensland, St Lucia Queensland 4072, Australia

137 KwaZulu-Natal Sharks Board, Umhlanga 4320, South Africa

148 Biomedical Resource Unit, University of KwaZulu-Natal, Durban 4000, South Africa

15

16

$17 *$ Corresponding author

18 Address: Marine Megafauna Foundation, Praia do Tofo, Inhambane, Mozambique

19 Phone: Mozambique (+258) 84 8142721; Tanzania (+255) 764900044

20 Email: chris@marinemegafauna.org 


\section{$21 \quad$ Introduction}

22 The whale shark Rhincodon typus (Smith 1828) is the world's largest fish species, measuring up to $232000 \mathrm{~cm}$ total length (TL) and $34 \mathrm{t}$ in mass (Chen, Liu \& Joung, 1997). Their large size, tendency to 24 spend much of their time at the surface (Wilson et al., 2006; Brunnschweiler et al., 2009; Motta et al., 25 2010) and predictable aggregative behaviour in certain coastal areas, make them susceptible to human 26 threats such as directed fisheries (Pravin, 2000), boat strikes and net entanglement (Speed et al., 2008).

27 Similar to most large sharks (Cortés, 2002), whale sharks are likely to grow and reach maturity slowly, 28 leaving them vulnerable to depletion caused by human pressures (Wintner, 2000; Cheung, Pitcher \& 29 Pauly, 2005).

31 Whale sharks were listed as Vulnerable on the IUCN Red List of Threatened Species following rapid 32 and substantial declines caused by targeted fisheries in the 1990s and early 2000s in the Indo-Pacific

33 (Norman, 2005). Although a decrease in whale shark sightings may not necessarily indicate a decrease 34 in actual whale shark numbers due to the highly mobile nature of these animals and variability in 35 sighting conditions, studies that controlled for environmental factors in southern Mozambique (200536 2011; Rohner et al., 2013) and at Ningaloo Reef, Western Australia (1995-2004; Bradshaw et al., 37 2008) revealed substantial declines in sightings. This suggests that some aggregations in the Indian 38 Ocean may have suffered population declines. Additional studies at Ningaloo Reef proposed that an 39 apparent decline in mean length of whale sharks (Bradshaw et al., 2008) may have resulted from 40 increased recruitment of smaller sharks to this location (Holmberg, Norman \& Arzoumanian, 2008), 41 rather than a decrease in survivorship of larger individuals (Bradshaw, Mollet \& Meekan, 2007;

42 Bradshaw et al., 2008). Such an interpretation would suggest that this regional population is recovering. 43 These apparently conflicting results may be due partly to methodological differences among studies. 44 Holmberg et al. (2008; 2009) used mark-recapture population models and excluded transient sharks, 45 whereas Bradshaw et al. (2007) used demographic models, which are highly sensitive to variation in 46 key biological parameters such as age or size at maturity. These parameters are poorly-known for 47 whale sharks, and this high uncertainty decreases the predictive capability of demographic models 48 (Simpfendorfer, 1999; Bradshaw et al., 2007). Determining life-history parameters is therefore crucial 49 to improving whale shark management. 
51 Generally, vertebral ageing studies are the source of most demographic data for elasmobranchs

52 (Cailliet et al., 2006; Pierce \& Bennett, 2010), but whale shark studies have been hampered by limited

53 sample sizes and the difficulty in validating age results (Wintner, 2000). An alternative approach has

54 been the use of growth rates on free-ranging sharks through the marking and recapture of individuals

55 (Pierce \& Bennett, 2009). In whale sharks, the common use of imprecise visual size estimation

56 (Rohner et al., 2011) has precluded routine collection of growth data, and consequently long-term

57 trends in mean lengths and growth should be interpreted cautiously.

59 Whale sharks show some degree of site fidelity (Holmberg et al., 2009; Rowat et al., 2011) that has

60 allowed for basic biological parameters to be estimated through visual assessment, despite most

61 aggregations being dominated by juvenile males. The length at which $50 \%$ of males reach maturity

$62\left(\mathrm{TL}_{50}\right)$ was estimated to be $\sim 810 \mathrm{~cm}$ at Ningaloo Reef (Norman \& Stevens, 2007), while growth rates

63 were estimated to be 3-70 $\mathrm{cm}$ year ${ }^{-1}$ in Belize (Graham \& Roberts, 2007) and $45 \mathrm{~cm}^{-1} \mathrm{ear}^{-1}$ in the

64 Maldives (Riley et al., 2010). However, visual size estimates can lack accuracy and precision,

65 particularly where multiple observers are involved (Holmberg et al., 2009). By contrast, paired-laser

66 photogrammetry (photogrammetry henceforth) is likely to be more accurate and precise (Rohner et al.,

67 2011).

68

69 Here, we use photogrammetry to measure whale sharks at two coastal aggregation sites in the

70 southwestern Indian Ocean; off Praia do Tofo (Tofo Beach) in southern Mozambique and off Kilindoni

71 on Mafia Island, Tanzania. First, we aimed to describe the size ranges and sex ratios of sharks at these

72 sites. Second, we aimed to assess length at which $50 \%$ of males reach maturity using total length and

73 clasper length measurements from photogrammetry of free-swimming whale sharks in southern

74 Mozambique and direct measurements of stranded individuals in northern South Africa. Third, we

75 aimed to test whether photogrammetry can detect growth rates estimated over a 1-3 year time period.

\section{Methods}

78 Study locations and whale shark searches

79 Photogrammetry data were collected from whale sharks off Praia do Tofo $\left(23.85^{\circ} \mathrm{S}, 35.56^{\circ} \mathrm{E}\right)$ in

80 southern Mozambique between January 2010 and October 2013 and off Mafia Island, Tanzania (7.90

$81 \mathrm{~S}, 39.66^{\circ} \mathrm{E}$ ) between October 2012 and December 2013 (Fig. 1). Whale sharks were spotted during 
82 boat-based searches (see Pierce et al., 2010), and all data were collected while snorkeling alongside the 83 sharks. Direct measurements of stranded sharks were obtained from Pomene, southern Mozambique $84\left(22.92^{\circ} \mathrm{S}, 35.56^{\circ} \mathrm{E}\right)$ and from the northern South African coast $\left(\sim 29.10^{\circ} \mathrm{S}, 31.64^{\circ} \mathrm{E}\right.$, Fig. 1$)$.

85 Unpublished photographic identification data (Wild Me, 2014) and satellite tagging results (Rohner, 86 2013) have demonstrated regular movements between northern South Africa and southern

87 Mozambique, hence we treat them as a single population. Data collection in Mozambique was cleared 88 by The University of Queensland's animal ethics committee (GPEM/184/12/MMF/SF) and research in 89 Tanzania was approved by the Tanzania Commission for Science and Technology (COSTECH).

\section{Photographic identification}

92 We first identified each whale shark that we measured with photogrammetry, by photographing the 93 area behind the gills and above the pectoral fin (Arzoumanian, Holmberg \& Norman, 2005). All

94 photographs were taken with Canon G11/G12 compact digital cameras. The zoom function was not 95 used. Identification photographs were submitted to the Wildbook for Whale Sharks library 96 (www.whaleshark.org) and processed to assign a unique identity to each shark. Sightings were 97 compared with images in the archived database of sharks to identify broader connectivity with other 98 sites.

\section{Photogrammetry analysis}

101 A laser photogrammetry system mounted on a housed digital camera, as described in Rohner et al. 102 (2011) and in Deakos (2010), was used to project two spots of green laser light (Sea Turtle Scuba Inc.;

$103<5 \mathrm{~mW}$ power) onto the flank of each shark while a photograph was taken. Only sharks which we could 104 measure photogrammetrically were included in all analyses. A photograph suitable for 105 photogrammetric analyses needed to feature the flank region from fifth gill slit to the start of the first 106 dorsal fin, both laser points had to be clearly visible, the shark had to be in a stretched position and the 107 photograph had to be taken from the same horizontal level of the shark and with the laser pointers 108 being at $\sim 90^{\circ}$ angle to the flank. Four observers took photogrammetry images, with the majority taken 109 by CAR and SJP ( $\sim 90 \%)$. Total length was extrapolated from a measurement of the flank between the $1105^{\text {th }}$ gill slit and the origin of the $1^{\text {st }}$ dorsal fin $\left(B_{\mathrm{P} 1}\right.$ in Rohner et al., 2011). This metric had a robust 111 linear correlation for whale sharks between $\sim 400-900 \mathrm{~cm}$ in length (Rohner et al., 2011). Where 112 possible, multiple laser photogrammetric images were taken of the shark in each encounter to measure 
$113 \mathrm{TL}$ and improve the morphometric relationship between TL and the distance from the $5^{\text {th }}$ gill slit to the

114 origin of the $1^{\text {st }}$ dorsal fin. All shark lengths are reported as total length unless otherwise specified.

115

116 Assessment of the laser photogrammetry set-up

117 We followed the methods described in Deakos (2010) to assess the laser photogrammetry setup:

118 Image distortion: The airspace between the camera lens and the underwater housing refracts the

119 incoming light and the shape of the lens itself can lead to image distortion. We thus quantified image

120 distortion of the photogrammetry setup empirically underwater. A grid of $10 \times 10$ squares was

121 photographed. The pixels across the diagonal of the middle two squares were counted and this number

122 was multiplied by 2, 3 and 4 to get the expected distance across 4,6 and 8 squares, respectively. The

123 observed and expected values (number of pixels) were plotted and a linear regression fitted to the data

124 to obtain the image distortion function:

$125 L_{\text {Expected }}=1.0339 \times L_{\text {Observed }}-31.516$

127 As the zoom on the camera was never used, this distortion function was constant (Harvey \& Shortis,

128 1998) and was applied to all photogrammetry image measurements.

130 Parallel alignment of lasers: Lasers must be parallel to provide accurate data from varying distances

131 to the target. The photogrammetry set-up was therefore regularly calibrated on land by measuring

132 points $50 \mathrm{~cm}$ apart from 3,5 and $8 \mathrm{~m}$ to the target. Photogrammetry images of whale sharks for size

133 analysis were consistently taken at $\sim 4 \mathrm{~m}$ from the shark, so that the maximum tested distance $(8 \mathrm{~m})$

134 was about twice that used for size estimation, and errors would have been, on average, half as large.

136 Parallax error: Parallax error would lead to an underestimate of shark length if a photogrammetry

137 image was not taken perpendicular to the target. The parallax error for our setup was assessed by

138 measuring a $50 \mathrm{~cm}$ long object 5 times each from an angle of $10^{\circ}, 20^{\circ}, 30^{\circ}, 40^{\circ}$ and $50^{\circ}$. The

139 percentage error was $2.9 \%, 8.3 \%, 16.6 \%, 27.5 \%$ and $39.1 \%$, respectively. In the field, we had no

140 means of estimating this angle for each photograph and thus correcting for potential parallax error.

141 Instead, we exclude all images that appeared to be taken at $>10^{\circ}$ angle. 
143 Finally, the accuracy and precision of the photogrammetry setup were assessed by measuring a 258.6 $144 \mathrm{~cm}$ pole 30 times underwater.

\section{Maturity assessment}

147 The sex of each whale shark was determined visually by examining the pelvic fins for the presence of 148 claspers, the external, paired reproductive structures of male sharks. Maturity in male sharks was 149 assessed by examining the length and thickness of claspers (Norman \& Stevens, 2007). Immature 150 sharks have relatively small, thin claspers, and mature sharks have thick claspers that extend past the 151 pelvic fins. Field observations suggest that whale shark claspers grow in length first before they get 152 thicker. We classified sharks as mature only if their claspers were both long and thick, indicating 153 calcification (Fig. 2). While clasper calcification in dead sharks is manually assessed, we think that 154 calcified, stiff claspers of mature whale sharks can also be visually determined. Claspers of 46 male 155 sharks from Mozambique and 22 sharks from Tanzania were measured using photogrammetry, while 156 claspers from 11 males that were stranded along the northeastern coast of South Africa were measured 157 directly. Clasper length (CL) was defined as the distance from the anterior end of the cloaca to the 158 posterior tip of the clasper, equivalent to clasper inner length in Compagno (2001). The TL and CL at 159 which $50 \%$ of males were mature $\left(\mathrm{TL}_{50}\right.$ and $\left.\mathrm{CL}_{50}\right)$ were each calculated using generalised linear 160 models (GLM), with a binary logit function. We minimised potential differences among measurements 161 of live, free-swimming sharks and dead, stranded specimens by measuring natural TL (Francis, 2006) 162 where possible, or scaling pre-caudal length (PCL) to TL based on a previously-derived morphometric 163 relationship: $T L=1.2182 * P C L+33.036(N=41)$ in 4 of the 11 stranded sharks (Wintner, 164 2000; Rohner et al., 2011).

166 Three whale sharks were found stranded on 16 August 2009 at Pomene Beach in southern 167 Mozambique (Fig. 1) and dissections were conducted on-site. The maturity status of the two female 168 sharks was based on the condition of the ovary and the uteri, and of the male through examination of 169 claspers, testes and accessory organs, similar to criteria in Pierce et al. (2009).

171 Age determination

172 To determine whale shark age, we used growth patterns in the vertebral centra, as is done in most age 173 and growth studies of elasmobranchs (Cailliet et al., 2006). Vertebrae anterior to the first dorsal fin 
174 were extracted from two of the stranded whale sharks from Mozambique; a $738 \mathrm{~cm}$ male and a $630 \mathrm{~cm}$

175 female. Vertebrae were stored frozen until x-radiography images were taken (Eklin EDR3 Mark III) to

176 visualise band pairs following Wintner (2000) as a method of determining age. Some elasmobranchs

177 lay down a pair of visually identifiable bands on their vertebrae as they grow (Cailliet et al., 2006).

178 These band pairs consist of one opaque and one translucent band and represent summer and winter,

179 respectively (Cailliet et al., 2006). We counted band pairs on two vertebrae from each shark. Three

180 readers assessed each vertebra three times, independently of one another, after which the median was

181 taken as a consensus count.

182

183 Growth rates

184 We tested whether in situ photogrammetry had enough precision to determine growth rates of 13 whale

185 sharks measured and subsequently re-measured over $>340$ days. Our growth rate estimates were

186 compared to growth derived from back-calculated size at age data, assuming annual band pair

187 formation. These data included band-pair counts from stranded sharks of known size from South Africa

188 (Wintner 2000) and from two of the sharks we dissected at Pomene, Mozambique. We produced a

189 linear regression with 95\% confidence intervals (CI) from back-calculated size at age values. The zero

190 value was set at $42 \mathrm{~cm}$ PCL following Wintner (2000), as this is the approximate size of newly-born

191 whale sharks (Joung et al., 1996; Chang, Leu \& Fang, 1997).

192

\section{Results}

194 Photogrammetry assessment

195 Length estimates of the $258.6 \mathrm{~cm}$ pole made with our photogrammetry equipment under controlled

196 conditions were within a mean error of $1.2 \%$ or $-3.2 \mathrm{~cm}$. Lengths ranged from $254.7-256.6 \mathrm{~cm}$ and all

197 measurements underestimated the true length. Precision was high, with a coefficient of variation of

$198 \quad 0.17 \%$.

199

200 Morphometric relationship for TL

201 The morphometric relationship used for estimating TL in Rohner et al. (2011) was based on 27 data

202 points, including 4 sharks from Japan. We updated this correlation here by including additional data

203 from 14 fully-measured live sharks and by removing the 4 data points from outside our study region.

204 The updated equation was: 


$$
T L=4.902 B P 1+72.579\left(r^{2}=0.92, N=37\right) .
$$

\section{Population structure}

209 The 123 measured whale sharks in southern Mozambique ranged from 439-934 cm, with a mean \pm SD

210 of $684 \pm 118 \mathrm{~cm}$ (Table 1). A significant sex bias was observed, with $75.7 \%$ male and $24.3 \%$ female in

211 the 115 sharks for which sex was determined (Chi-square test, $\chi^{2}=26.420, \mathrm{P}<0.001$ ). Mean male size

212 (range $=445-934 \mathrm{~cm}$, mean $\pm \mathrm{SD}=692 \pm 119 \mathrm{~cm}, \mathrm{~N}=87$ ) did not differ significantly from mean

213 female size $($ range $=439-858 \mathrm{~cm}$, mean $\pm \mathrm{SD}=670 \pm 108 \mathrm{~cm}, \mathrm{~N}=28)(\mathrm{t}$ test, $\mathrm{t}=0.67, \mathrm{df}=49.65, \mathrm{p}=$

214 0.506), although all 6 sharks $>860 \mathrm{~cm}$ were male (Fig. 3a).

215

216 The 56 whale sharks measured in Tanzania ranged from 420-990 cm, with a mean of $655 \pm 129 \mathrm{~cm}$

217 (Table 1). A significant sex bias was present, with $87.5 \%$ male and $12.5 \%$ female in the 56 measured

218 sharks for which sex was determined (Chi-square test, $\left.\chi^{2}=56.3, \mathrm{P}<0.001\right)$. The mean length of males

$219(660 \pm 131 \mathrm{~cm}, \mathrm{~N}=49)$ and females $(620 \pm 117 \mathrm{~cm}, \mathrm{~N}=7)$ were not significantly different $(\mathrm{t}=0.84, \mathrm{df}$ $220=8.32, \mathrm{p}=0.425)$ (Fig. 3b).

222 Size at maturity

223 Inner clasper lengths (CL) were measured for 46 sharks from Mozambique, 11 from South Africa and 22422 from Tanzania. Eight sharks ranging from 823-1032 cm were mature and had clasper lengths 225 ranging from $75-106 \mathrm{~cm}$. The largest immature male was $928 \mathrm{~cm}$ and clasper length of immature 226 males ranged from $26-84 \mathrm{~cm}$ (Fig. 4).

228 Based on the established connectivity between Mozambique and South Africa, we combined maturity 229 data from stranded whale sharks in northeastern South Africa and Pomene (Mozambique) with data 230 from whale sharks measured with photogrammetry in Mozambique. Maturity $\left(\mathrm{TL}_{50}\right)$ was attained at $231916 \mathrm{~cm}($ Residual Deviance $=19.9 ; \mathrm{p}=0.012 ; \mathrm{AIC}=23.9)$, and $\mathrm{CL}_{50}$ was $81.0 \mathrm{~cm}($ Residual Deviance $=$ $2326.81 ; \mathrm{p}=0.02 ; \mathrm{AIC}=10.81$; Fig. 5). One $876 \mathrm{~cm}$ mature male from Tanzania had a CL of $89 \mathrm{~cm}$. It was 233 slightly smaller than the largest immature shark $(\mathrm{cf} .903 \mathrm{~cm})$, but had longer claspers $(\mathrm{cf} .74 \mathrm{~cm})$. The 3 234 stranded sharks examined at Pomene measuring $738 \mathrm{~cm}$ (male), $630 \mathrm{~cm}$ (female) and $820 \mathrm{~cm}$ (female), 
235 were immature. The larger female had thin, strap-like uteri and a lattice-like ovary structure. No

236 ovarian follicles were observed.

238 Ageing and natural growth rates

239 Vertebrae of the $738 \mathrm{~cm}$ male and the $630 \mathrm{~cm}$ female had 26 and 22 band pairs, respectively. These

240 data were added to the band pair counts of 15 whale sharks from Wintner (2000) to create an updated

241 regression for band pair counts and length:

$P C L=22.44 *$ band pairs $+29.46\left(r^{2}=0.99, N=17\right)$.

244 Over the study period, we resighted $72 \%$ and $96 \%$ of measured individuals from Mozambique and

245 Tanzania, respectively. Seven sharks from Mozambique and 24 sharks from Tanzania were measured

246 multiple times over the study period, with a time gap of 3-1068 days. Of these, 13 individuals were re-

247 measured after more than 340 days had elapsed since the time of the initial size estimate and were used

248 to examine growth. Mean growth rate was $5.6 \mathrm{~cm}_{\text {year-1 }}( \pm 47.3)$, with 6 sharks having decreased in

249 length when re-measured (Fig. 6).

\section{Discussion}

252 Photogrammetry improved the accuracy of whale shark size estimates. While the estimated error in 253 visually-determined lengths of whale sharks was $\sim 10 \%$ (Rohner et al., 2011), our controlled tests of a 254 stationary target showed that photogrammetry can greatly reduced this error. Precision was also high, 255 with a CV of $0.17 \%$, so length estimates were consistent across photographs. Jeffreys et al. (2012) also 256 found high accuracy and precision in experimental tests of a similar photogrammetry set-up. The 257 major challenge with photogrammetry of whale sharks remains taking an image from the correct 258 horizontal and vertical angle while the shark is in a straight, flexed position. Measuring only a portion 259 of the body, such as PCL or $B_{\mathrm{P} 1}$, enhances precision as it excludes the caudal fin or the whole posterior 260 part of the body which can be flexed when the shark is swimming and results in out of plane 261 (foreshortened) images. We used $B_{\mathrm{P} 1}$ to scale TL in preference over the distance from the spiracle to 262 the $5^{\text {th }}$ gill slit (A1 in Jeffreys et al., 2012). This was because sharks in our study were mostly surface 263 feeding, which resulted in a dorso-ventral flexion of the head that precluded an assessment of the A1 264 metric. Although the TL data used in our study are derived from a morphometric relationship between 
$265 B_{\mathrm{P} 1}$ and TL $\left(\mathrm{r}^{2}=0.92\right)$, our measurements are considered to be more accurate than those derived from 266 visual estimates.

268 Sex- and size-based segregation

269 Whale sharks measured in Mozambique and Tanzania exhibited pronounced sex- and size-based 270 segregation. Most sharks were juvenile males of $550-850 \mathrm{~cm}$, which is similar to other known whale 271 shark aggregation sites in the Indian Ocean and elsewhere (Fig. 7 with references in the caption).

272 Given that whale sharks can reach $2000 \mathrm{~cm}$ (Chen et al., 1997), the size structure observed in these 273 aggregations show that only a proportion of a whale shark population is seen at these coastal sites.

274 Mean sizes of $684 \mathrm{~cm}$ in Mozambique and $640 \mathrm{~cm}$ in Tanzania were considerably larger than that 275 recorded from Djibouti, Saudi Arabia, Taiwan and inshore sites in the Gulf of Mexico. These sites 276 appear to be dominated by small juveniles, while a larger size range of juveniles is present in

277 Mozambique and Tanzania. By contrast, whale sharks here were considerably smaller than at offshore 278 sites in the Gulf of Mexico where mostly large, mature females are seen (Fig. 7 with references in the caption). Size ranges of 439-934 cm observed in Mozambique and 415-971 cm in Tanzania were 280 smaller than reported for most other locations, although this may partly be a consequence of the 281 improved precision of size estimates from photogrammetry in comparison to visual estimates and the 282 comparatively short time-frame of this study.

284 A male sex bias is common at monitored whale shark aggregation sites. The percentage of male sharks 285 in Mozambique (76\%) was similar to northeastern South Africa (73\%) and inshore sites in the Gulf of 286 California (75\%), but lower than that in Tanzania (88\%), the Maldives (95\%), Djibouti (83\%), 287 Ningaloo Reef (85\%) or the Seychelles (82\%) (Fig. 7). By contrast, the coastal aggregation in Saudi 288 Arabia had about equal numbers of juvenile males and females, whereas offshore sites in the Gulf of 289 California and the Galapagos Islands mainly had large females (Ketchum, Galván-Magaña \& Klimley, 290 2012; Ramírez-Macías, Vázquez-Haikin \& Vázquez-Juárez, 2012b; Hearn et al., 2013; Berumen et al., 291 2014). The apparent sex bias and the narrow size range of whale sharks across the Indian Ocean 292 aggregation sites raises intriguing questions concerning the location of newborn, female, and larger 293 mature sharks. Whale sharks are born at $45-60 \mathrm{~cm}$ (Joung et al., 1996; Chang et al., 1997), but <250 $294 \mathrm{~cm}$ individuals are rarely seen anywhere in the world and there are only 19 reports of sharks $<150 \mathrm{~cm}$ 295 (Rowat \& Brooks, 2012). The sex ratio of whale shark embryos was almost equal (1: 0.98 females to 
296 males, $\mathrm{N}=297$ ) in the only pregnant whale shark investigated to date (Chang et al., 1997). Chang et al.

297 (1997) found no inter-sex difference in the length or mass of embryos and hence female neonates are

298 assumed to have similar survival rates to males. The pronounced segregation in most coastal whale

299 shark aggregations suggests that whale sharks occupy different habitats, or use the same habitats

300 differently, depending on their sex and size.

302 While the sex bias and the predominance of immature whale sharks at coastal sites could conceivably

303 be an artifact of the previous targeted fisheries activities in the Indian Ocean and Western Pacific, there

304 are several arguments against this being the case in Mozambique and Tanzania. First, there appears to

305 be little or no connectivity among the largest whale shark aggregations in the Indian Ocean (Wilson et

306 al., 2006; Brooks et al., 2010; Sleeman et al., 2010). This suggests that fisheries in the Maldives, India,

307 or further away in Taiwan and the Philippines should not have affected the population structure in the

308 Western Indian Ocean, although they may have led to declines in the east at Ningaloo Reef (Bradshaw

309 et al., 2007, 2008) and off Thailand (Theberge \& Dearden, 2006). Second, evidence suggests that the

310 majority of sharks caught in fisheries were males or juveniles. Most sharks landed in Taiwan were

311 juvenile males (Hsu, Joung \& Liu, 2012). A large proportion of the catch from India contained

312 immature sharks, though the sex of the sharks was not reported (Pravin, 2000). Interviews with fishers

313 and catch records from the Philippines also indicated that landed sharks were largely immature, again

314 with no information on the sex ratio (Alava \& Dolumbalo, 2002). Last, coastal whale shark

315 aggregations in and around the Caribbean Sea, where there is no history of fishing for whale sharks, are

316 also dominated by immature male sharks (Graham \& Roberts, 2007; Ramírez-Macías et al., 2012a, Fox

317 et al., 2013). Therefore, data suggest that juvenile and male dominated whale shark aggregations are

318 natural and not necessary an artifact of selective fishing pressures.

320 Segregation is common in many shark species, with populations usually divided socially and/or 321 geographically into units of sub-adults, mature males and mature females (Springer, 1967; Klimley,

322 1987; Richardson et al., 2000; Bansemer \& Bennett, 2011). This is thought to be due to differences in

323 diet or swimming capabilities or to reduce intra-specific competition, aggression and predation

324 (Springer, 1967; Wearmouth \& Sims, 2008). The reason for the prevalence of juvenile male whale

325 sharks at known aggregation sites is unclear, and although different diet preferences for juveniles and

326 adults has been suggested (Ketchum et al., 2012), this does not explain the sex bias. The segregation 
observed in Mozambique, Tanzania and elsewhere indicates that larger individuals and neonates use different habitats than juveniles. Similarly, mature sharks of both sexes are not often seen at coastal sites and may be completely oceanic. Although few data are available from the Indian Ocean, large mature sharks are regularly seen in the open ocean in other areas (Hazin et al., 2008; Hearn et al., 2013; Afonso, McGinty \& Machete, 2014). Their larger size and superior swimming efficiency may enable them to move further horizontally and vertically and thus forage more successfully in a patchy offshore prey landscape (Sims et al., 2006).

\section{Size at maturity}

Our $\mathrm{TL}_{50}$ of male whale sharks was $916 \mathrm{~cm}, \sim 100 \mathrm{~cm}$ larger (13\% of total length) than that visually estimated for Ningaloo Reef sharks (Norman \& Stevens, 2007), and $200 \mathrm{~cm}$ larger (24\% of total length) than those off the Yucatan coast of Mexico (Ramírez-Macías et al., 2012a). These large differences are potentially significant, and suggest genuine biological differences among sharks using these sites. Regional differences among sizes at maturity or life-history traits of elasmobranch species are not uncommon, and have been documented in bonnethead sharks Sphyrna tiburo (LombardiCarlson et al., 2003), greeneye spurdog shark Squalus mitsukurri and porbeagle sharks Lamna nasus (Francis \& Duffy, 2005), and cownose rays Rhinoptera bonasus (Neer \& Thompson, 2005), among others. Evidence from mitochondrial and microsatellite DNA showed that Atlantic and Indo-Pacific whale sharks never or rarely mix, while no evidence of stock structure was found within the Indian Ocean (Vignaud et al., 2014). The marked difference in $\mathrm{TL}_{50}$ between Mozambique and the Yucatan coast of Mexico thus is consistent with these genetic results. It is unclear whether our photogrammetric results are directly comparable with the visual size estimates from Ningaloo Reef (Norman \& Stevens, 2007) due to the differing methods employed. While there are no genetically distinct stocks of whale sharks within the Indian Ocean (Vignaud et al., 2014), photo-matching (Brooks et al., 2010) and tracking studies (Wilson et al., 2006; Sleeman et al., 2010) have not demonstrated any interchange between the eastern and western Indian Ocean populations. There may thus be population differentiation among Indian Ocean whale shark aggregations on a shorter time-scale than detected in genetic studies. A significant size-at-maturity difference between the eastern and western Indian Ocean, if it does exist, would suggest population-level separation within this ocean basin. 
357 Mature female whale sharks are rarely observed and all sharks $>900 \mathrm{~cm}$ observed in our study were

358 male. While it is impossible to assess maturity in females externally, in the absence of visible

359 pregnancy, females of $820 \mathrm{~cm}$ (this study), $870 \mathrm{~cm}$ (Beckley et al., 1997) and $880 \mathrm{~cm}$ (Pai,

360 Nandakumar \& Telang, 1983) examined in the Indian Ocean were immature. The only directly-

361 measured mature female to date was $1060 \mathrm{~cm}$ (Joung et al., 1996), and mature females in the Gulf of

362 California were visually-estimated at 900-1300 cm (Ramírez-Macías et al., 2012b). Potential stock

363 differences notwithstanding, this suggests that none of the females in our study were mature.

\section{Applicability of laser photogrammetry to estimating growth rate}

366 Laser photogrammetry is clearly an improvement on the standard method of estimating length visually,

367 but our results indicate that it is not sufficiently precise for measuring growth rates of individuals over

368 short time spans (a few years) relative to their $\sim 80$ year lifespan (Hsu et al. 2014). The negative growth

369 rates we estimated are likely to reflect this limitation. Although we demonstrated the accuracy of

370 measurement for a static target of known length, it was not possible to document the accuracy of the

371 technique when applied to a free-swimming whale shark, as there was no way of knowing the true

372 length of the subject shark. It would be best to make repeat measurements on the same individuals on

373 the same day to evaluate precision, although this was not possible in our study because we could not

374 re-measure individuals on the same day. Our summary is that laser photogrammetry is useful for

375 routine length measurement of whale sharks, but should not be used for estimating growth rates over

376 short (1-3 year) periods. However, it may remain useful for measuring growth over long periods

377 (decades).

378

379 In conclusion, laser photogrammetry estimates are likely to be more accurate and precise than visual

380 estimates of length and size at maturity, but we suggest that they are not used for growth rate estimates

381 over short time periods. Accurate measurement of life-history parameters can improve demographic

382 models for the whale shark and thus facilitate better assessment of its vulnerability to fishing pressures

383 or recovery from population declines. We also show that the size range and sex ratio of whale sharks

384 from Mozambique and Tanzania are similar to those at most other aggregation sites globally, in that the

385 population consisted largely of $\sim 450-950 \mathrm{~cm}$ juvenile sharks, most of which were males. The observed

386 population segregation by size and sex reinforces the need to determine the whereabouts of young-of- 
the-year and small juvenile sharks, immature female sharks, and mature sharks of both sexes to improve conservation and management for this globally threatened species.

Acknowledgements We thank P. Bassett, Marine Megafauna Foundation volunteers and staff and All Out Africa volunteers for assistance with fieldwork in Mozambique. Casa Barry Lodge and Peri-Peri Divers provided field support in Mozambique. We thank Jason Rubens, Haji Machano, Jesse Cochran and Fernando Cagua for facilitating fieldwork in Tanzania. Liberatus Mokoki and Jean and Anne de Viliers provided field support in Tanzania. We also thank N. Ayliffe for help with whale shark dissections in Pomene and the Baker \& McVeigh Equine Hospital in Summerveld, KZN for taking xradiography images of the vertebrae. We thank the Editors David Johnston and John Bruno as well as Mark Deakos and two anonymous reviewers for their comments on the draft manuscript, which have considerably improved our paper.

Funding This study was supported by the Shark Foundation, GLC Charitable Trust, Rufford Small Grants, Project AWARE International, Ocean Revolution, Fondation Ensemble, WWF Tanzania and one anonymous donor.

\section{References}

Afonso P, McGinty N, Machete M. 2014. Dynamics of whale shark occurrence at their fringe oceanic habitat. PloS ONE 9:e102060.

Alava MNR, Dolumbalo ERZ. 2002. Fishery and trade of whale sharks and manta rays in the Bohol Sea, Philippines. Elasmobranch Biodiversity, Conservation and Management: Proceedings of the International Seminar and Workshop, Gland, Shark Specialist Group, IUCN 1997:132-148.

Arzoumanian Z, Holmberg J, Norman B. 2005. An astronomical pattern-matching algorithm for computer-aided identification of whale sharks Rhincodon typus. Journal of Applied Ecology 42:999-1011.

Bansemer CS, Bennett MB. 2011. Sex- and maturity-based differences in movement and migration patterns of grey nurse shark, Carcharias taurus, along the eastern coast of Australia. Marine and Freshwater Research 62(6):596-606.

Beckley LE, Cliff G, Smale MJ, Compagno LJ V. 1997. Recent strandings and sightings of whale sharks in South Africa. Environmental Biology of Fishes 50:343-348. 
Berumen ML, Braun CD, Cochran JEM, Skomal GB, Thorrold SR. 2014. Movement patterns of juvenile whale sharks tagged at an aggregation site in the Red Sea. PloS ONE 9:e103536.

Bradshaw CJA, Fitzpatrick B, Steinberg C, Brook B, Meekan MG. 2008. Decline in whale shark size and abundance at Ningaloo Reef over the past decade: The world's largest fish is getting smaller. Biological Conservation 141:1894-1905.

Bradshaw CJA, Mollet HF, Meekan MG. 2007. Inferring population trends for the world's largest fish from mark-recapture estimates of survival. The Journal of Animal Ecology 76:480-9.

Brooks K, Rowat D, Pierce SJ, Jouannet D, Vely M. 2010. Seeing Spots: Photo-identification as a regional tool for whale shark identification. Western Indian Ocean Journal of Marine Science 9:185-194.

Brunnschweiler JM, Baensch H, Pierce SJ, Sims DW. 2009. Deep-diving behaviour of a whale shark Rhincodon typus during long-distance movement in the western Indian Ocean. Journal of Fish Biology 74:706-14.

Cailliet GM, Smith WD, Mollet HF, Goldman KJ. 2006. Age and growth studies of chondrichthyan fishes: the need for consistency in terminology, verification, validation, and growth function fitting. Environmental Biology of Fishes 77:211-228.

Chang W, Leu M, Fang L. 1997. Embryos of the whale shark, Rhincodon typus: Early growth and size distribution. Copeia 1997:444-446.

Chen C, Liu K-M, Joung S-J. 1997. Preliminary report on Taiwan's whale shark fishery. TRAFFIC Bulletin 17:53-57.

Cheung WWL, Pitcher TJ, Pauly D. 2005. A fuzzy logic expert system to estimate intrinsic extinction vulnerabilities of marine fishes to fishing. Biological Conservation 124:97-111.

Chidlow JA, Simpfendorfer CA, Russ GR. 2007. Variable growth band deposition leads to age and growth uncertainty in the western wobbegong shark, Orectolobus hutchinsi. Marine and Freshwater Research 58:856-865.

Compagno LJ V. 2001. FAO Species Catalogue for Fishery Purposes No. 1. Sharks of the World: An Annotated and Illustrated Catalogue of Shark Species Known to Date, vol. 2: Bullhead, Mackerel and Carpet Sharks (Heterodontiformes, Lamniformes and Orectolobiformes).

Cortés E. 2002. Incorporating uncertainty into demographic modeling: Application to shark populations and their conservation. Conservation Biology 16:1048-1062.

Davenport S, Stevens JD. 1988. Age and growth of two commercially imported sharks (Carcharhinus tilstoni and C. sorrah) from Northern Australia. Australian Journal of Marine and Freshwater Research 39:417-433. 
Fox S, Foisy I, De La Parra Venegas R, Galván Pastoriza BE, Graham RT, Hoffmayer ER, Holmberg J, Pierce SJ. 2013. Population structure and residency of whale sharks Rhincodon typus at Utila, Bay Islands, Honduras. Journal of Fish Biology 83:574-87.

Francis MP. 2006. Morphometric minefields - towards a measurement standard for chondrichthyan fishes. Environmental Biology of Fishes 77(3-4):407-421.

Francis MP, Campana SE, Jones CM. 2007. Age under-estimation in New Zealand porbeagle sharks (Lamna nasus): is there an upper limit to ages that can be determined from shark vertebrae? Marine and Freshwater Research 58:10-23.

Francis MP, Duffy C. 2005. Length at maturity in three pelagic sharks (Lamna nasus, Isurus oxyrinchus, and Prionace glauca) from New Zealand. Fishery Bulletin 103:489-500.

Graham RT, Roberts CM. 2007. Assessing the size, growth rate and structure of a seasonal population of whale sharks (Rhincodon typus Smith 1828) using conventional tagging and photo identification. Fisheries Research 84:71-80.

Harvey ES, Shortis MR. 1998. Calibration stability of an underwater stereo video system: Implications for measurement accuracy and precision. Marine Technology Society Journal 32:3-17.

Hazin FH V, Vaske Júnior T, Oliveira PG, Macena BCL, Carvalho F. 2008. Occurrences of whale shark (Rhincodon typus Smith, 1828) in the Saint Peter and Saint Paul archipelago, Brazil. Brazilian Journal of Biology = Revista Brasleira de Biologia 68:385-9.

Hearn AR, Green JR, Espinoza E, Peñaherrera C, Acuña D, Klimley A. 2013. Simple criteria to determine detachment point of towed satellite tags provide first evidence of return migrations of whale sharks (Rhincodon typus) at the Galapagos Islands, Ecuador. Animal Biotelemetry 1:11.

Hobbs J-PA, Frisch AJ, Hamanaka T, McDonald CA, Gilligan JJ, Neilson J. 2009. Seasonal aggregation of juvenile whale sharks (Rhincodon typus) at Christmas Island, Indian Ocean. Coral Reefs 28:577-577.

Holmberg J, Norman B, Arzoumanian Z. 2008. Robust, comparable population metrics through collaborative photo-monitoring of whale sharks Rhincodon typus. Ecological Applications 18:222-33.

Holmberg J, Norman B, Arzoumanian Z. 2009. Estimating population size, structure, and residency time for whale sharks Rhincodon typus through collaborative photo-identification. Endangered Species Research 7:39-53.

Hsu HH, Joung S-J, Hueter R, Liu K-M 2014. Age and growth of the whale shark Rhincodon typus in the northwestern Pacific. Marine and Freshwater Research 65(12):1145-1154.

Hsu HH, Joung SJ, Liu KM. 2012. Fisheries, management and conservation of the whale shark Rhincodon typus in Taiwan. Journal of Fish Biology 80:1595-607. 
Hussey NE, Cocks DT, Dudley SFJ, McCarthy ID, Wintner SP. 2009. The condition conundrum: application of multiple condition indices to the dusky shark Carcharhinus obscurus. Marine Ecology Progress Series 380:199-212.

Jeffreys GL, Rowat D, Marshall H, Brooks K. 2012. The development of robust morphometric indices from accurate and precise measurements of free-swimming whale sharks using laser photogrammetry. Journal of the Marine Biological Association of the United Kingdom 93:309320.

Joung S-J, Chen C-T, Clark E, Uchida S, Huang WYP. 1996. The whale shark, Rhincodon typus, is a livebearer: 300 embryos found in one "megamamma" supreme. Environmental Biology of Fishes 46:219-223.

Ketchum JT, Galván-Magaña F, Klimley AP. 2012. Segregation and foraging ecology of whale sharks, Rhincodon typus, in the southwestern Gulf of California. Environmental Biology of Fishes 96:779-795.

Klimley AP. 1987. The determinants of sexual segregation in the scalloped hammerhead shark, Sphyrna lewini. Environmental Biology of Fishes 18(1):27-40.

Lombardi-Carlson LA, Cortés E, Parsons GR, Manire CA. 2003. Latitudinal variation in life-history traits of bonnethead sharks, Sphyrna tiburo, (Carcharhiniformes: Sphyrnidae) from the eastern Gulf of Mexico. Marine and Freshwater Research 54:875-883.

Motta PJ, Maslanka M, Hueter RE, Davis RL, de la Parra R, Mulvany SL, Habegger ML, Strother JA, Mara KR, Gardiner JM, Tyminsk JP, Zeigler LD. 2010. Feeding anatomy, filter-feeding rate, and diet of whale sharks Rhincodon typus during surface ram filter feeding off the Yucatan Peninsula, Mexico. Zoology 113:199-212.

Natanson L, Wintner S, Johansson F, Piercy A, Campbell P, De Maddalena A, Gulak S, Human B, Fulgosi F, Ebert DA, Hemida F, Mollen FH, Vanni S, Burgess GH, Compagno LJV, WedderburnMaxwell A. 2008. Ontogenetic vertebral growth patterns in the basking shark Cetorhinus maximus. Marine Ecology Progress Series 361:267-278.

Neer JA, Thompson BA. 2005. Life history of the cownose ray, Rhinoptera bonasus, in the northern Gulf of Mexico, with comments on geographic variability in life history traits. Environmental Biology of Fishes 73:321-331.

Norman B. 2005. Rhincodon typus. IUCN Red List of Threatened Species. Version 2012-1:1-24.

Norman BM, Stevens JD. 2007. Size and maturity status of the whale shark (Rhincodon typus) at Ningaloo Reef in Western Australia. Fisheries Research 84:81-86.

Pai M V, Nandakumar G, Telang KY. 1983. On a whale shark Rhineodon typus Smith landed at Karwar, Karnataka. Indian Journal of Fisheries 30:157-160. 
Pierce SJ, Bennett MB. 2009. Validated annual band-pair periodicity and growth parameters of bluespotted maskray Neotrygon kuhlii from south-east Queensland, Australia. Journal of Fish Biology 75:2490-2508.

Pierce SJ, Bennett MB. 2010. Destined to decline? Intrinsic susceptibility of the threatened estuary stingray to anthropogenic impacts. Marine and Freshwater Research 61:1468-1481.

Pierce SJ, Méndez-Jiménez A, Collins K, Rosero-Caicedo M, Monadjem A. 2010. Developing a Code of Conduct for whale shark interactions in Mozambique. Aquatic Conservation: Marine and Freshwater Ecosystems 20:782-788.

Pierce SJ, Pardo SA, Bennett MB. 2009. Reproduction of the blue-spotted maskray Neotrygon kuhlii (Myliobatoidei: Dasyatidae) in south-east Queensland, Australia. Journal of Fish Biology 74:1291-1308.

Pravin P. 2000. Whale shark in the Indian coast - Need for conservation. Current Science 79:310-315.

Ramírez-Macías D, Meekan M, De La Parra-Venegas R, Remolina-Suárez F, Trigo-Mendoza M, Vázquez-Juárez R. 2012a. Patterns in composition, abundance and scarring of whale sharks Rhincodon typus near Holbox Island, Mexico. Journal of Fish Biology 80:1401-16.

Ramírez-Macías D, Vázquez-Haikin A, Vázquez-Juárez R. 2012b. Whale shark Rhincodon typus populations along the west coast of the Gulf of California and implications for management. Endangered Species Research 18:115-128.

Richardson AJ, Maharaj G, Compagno LJ V, Leslie RW, Ebert DA, Gibbons MJ. 2000. Abundance, distribution, morphometrics, reproduction and diet of the Izak catshark. Journal of Fish Biology 56:552-576.

Riley M, Hale M, Harman A, Rees R. 2010. Analysis of whale shark Rhincodon typus aggregations near South Ari Atoll, Maldives Archipelago. Aquatic Biology 8:145-150.

Rohner CA. 2013. A global whale shark hotspot in southern Mozambique: population structure, feeding ecology, movements and environmental drivers. PhD thesis, The University of Queensland, Australia.

Rohner CA, Pierce SJ, Marshall AD, Weeks SJ, Bennett MB, Richardson AJ. 2013. Trends in sightings and environmental influences on a coastal aggregation of manta rays and whale sharks. Marine Ecology Progress Series 482:153-168.

Rohner CA, Richardson AJ, Marshall AD, Weeks SJ, Pierce SJ. 2011. How large is the world's largest fish? Measuring whale sharks Rhincodon typus with laser photogrammetry. Journal of Fish Biology 78:378-85.

Rowat D, Brooks KS. 2012. A review of the biology, fisheries and conservation of the whale shark Rhincodon typus. Journal of Fish Biology 80:1019-56. 
Rowat D, Brooks K, March A, McCarten C, Jouannet D, Riley L, Jeffreys G, Perri M, Vely M, Pardigon B. 2011. Long-term membership of whale sharks (Rhincodon typus) in coastal aggregations in Seychelles and Djibouti. Marine and Freshwater Research 62:621.

Simpfendorfer CA. 1999. Mortality estimates and demographic analysis for the Australian sharpnose shark, Rhizoprionodon taylori, from northern Australia. Fisheries Bulletin 97:978-986.

Sims DW, Witt MJ, Richardson AJ, Southall EJ, Metcalfe JD. 2006. Encounter success of free-ranging marine predator movements across a dynamic prey landscape. Proceedings of the Royal Society B: Biological sciences 273:1195-201.

Sleeman JC, Meekan MG, Wilson SG, Polovina JJ, Stevens JD, Boggs GS, Bradshaw CJA. 2010. To go or not to go with the flow: Environmental influences on whale shark movement patterns. Journal of Experimental Marine Biology and Ecology 390:84-98.

Speed CW, Meekan MG, Rowat D, Pierce SJ, Marshall AD, Bradshaw CJA. 2008. Scarring patterns and relative mortality rates of Indian Ocean whale sharks. Journal of Fish Biology 72:1488-1503.

Springer S. 1967. Social organization of shark populations. In: Sharks, Skates and Rays. 149-174.

Stevenson RD, Woods WA. 2006. Condition indices for conservation: new uses for evolving tools. Integrative and Comparative Biology 46:1169-1190.

Theberge MM, Dearden P. 2006. Detecting a decline in whale shark Rhincodon typus sightings in the Andaman Sea, Thailand, using ecotourist operator-collected data. Oryx 40:337.

Vignaud TM, Maynard JA, Leblois R, Meekan MG, Vazques-Juarez R, Ramírez-Macías D, Pierce SJ, Rowat D, Berumen ML, Beeravolu C, Baksay S, Planes S. 2014. Genetic structure of populations of whale sharks among ocean basins and evidence for their historic rise and recent decline. Molecular Ecology 23(10)2590-2601.

Wearmouth VJ, Sims DW. 2008. Sexual segregation in marine fish, reptiles, birds and mammals: Behaviour patterns, mechanisms and conservation implications. Advances in Marine Biology 54:107-170.

Wild Me. 2014. ECOCEAN - The Global Whale Shark Database www.whaleshark.org.

Wilson SG, Polovina JJ, Stewart BS, Meekan MG. 2006. Movements of whale sharks (Rhincodon typus) tagged at Ningaloo Reef, Western Australia. Marine Biology 148:1157-1166.

Wintner SP. 2000. Preliminary study of vertebral growth rings in the whale shark, Rhincodon typus, from the east coast of South Africa. Environmental Biology of Fishes 59:441-451. 


\section{PeerJ Reviewing Manuscript}


1

Maps of the study locations

Fig. 1 The study locations off (A) Praia do Tofo in southern Mozambique and (B) Mafia Island in Tanzania, with (C) an inset of Africa for overview.

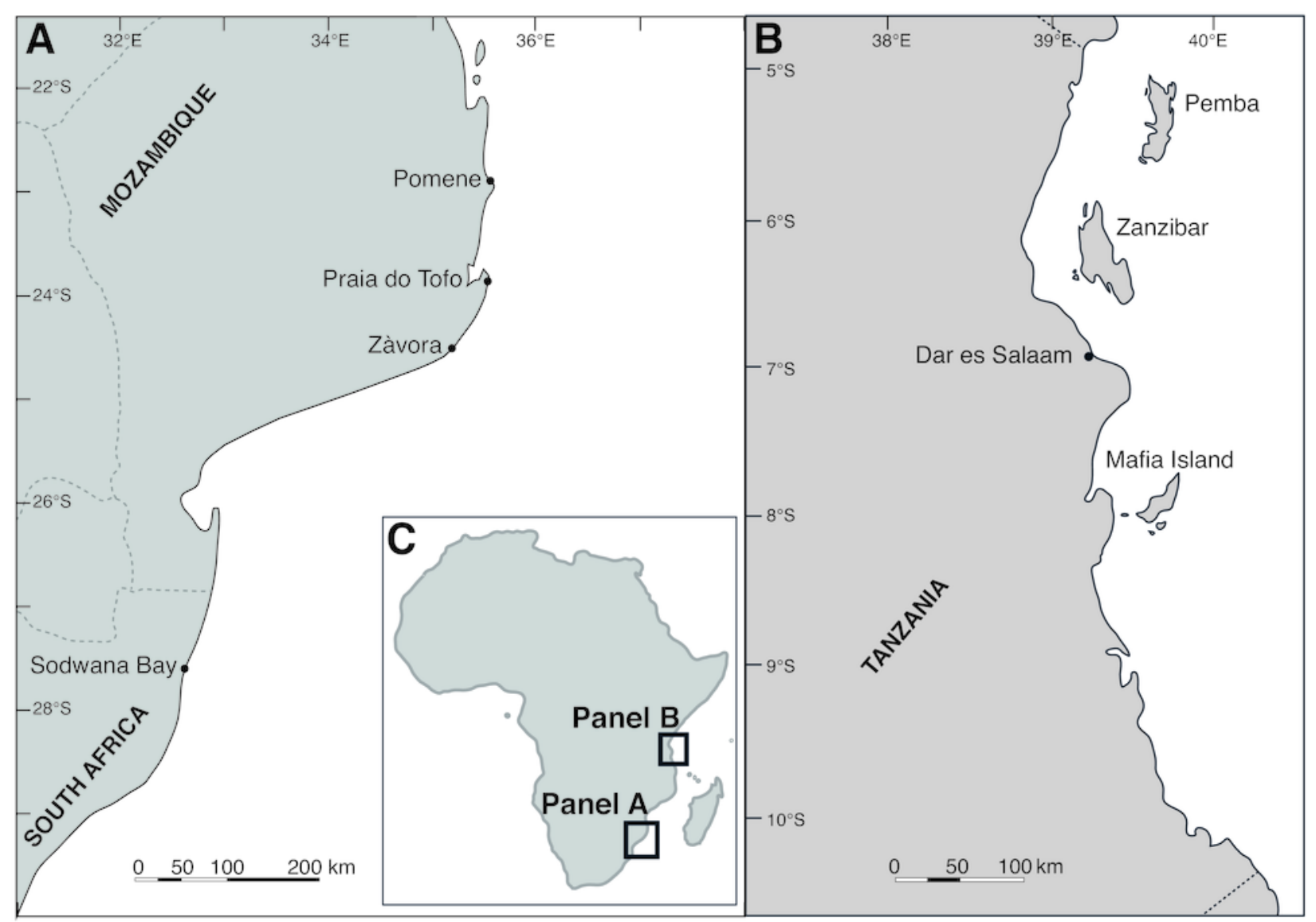


2

Laser photogrammetry improves size and demographic estimates for whale sharks Claspers of an immature and a mature shark

Laser photogrammetry improves size and demographic estimates for whale sharks Fig. 2 Claspers of (a) an immature male; and (b) a mature male whale shark.

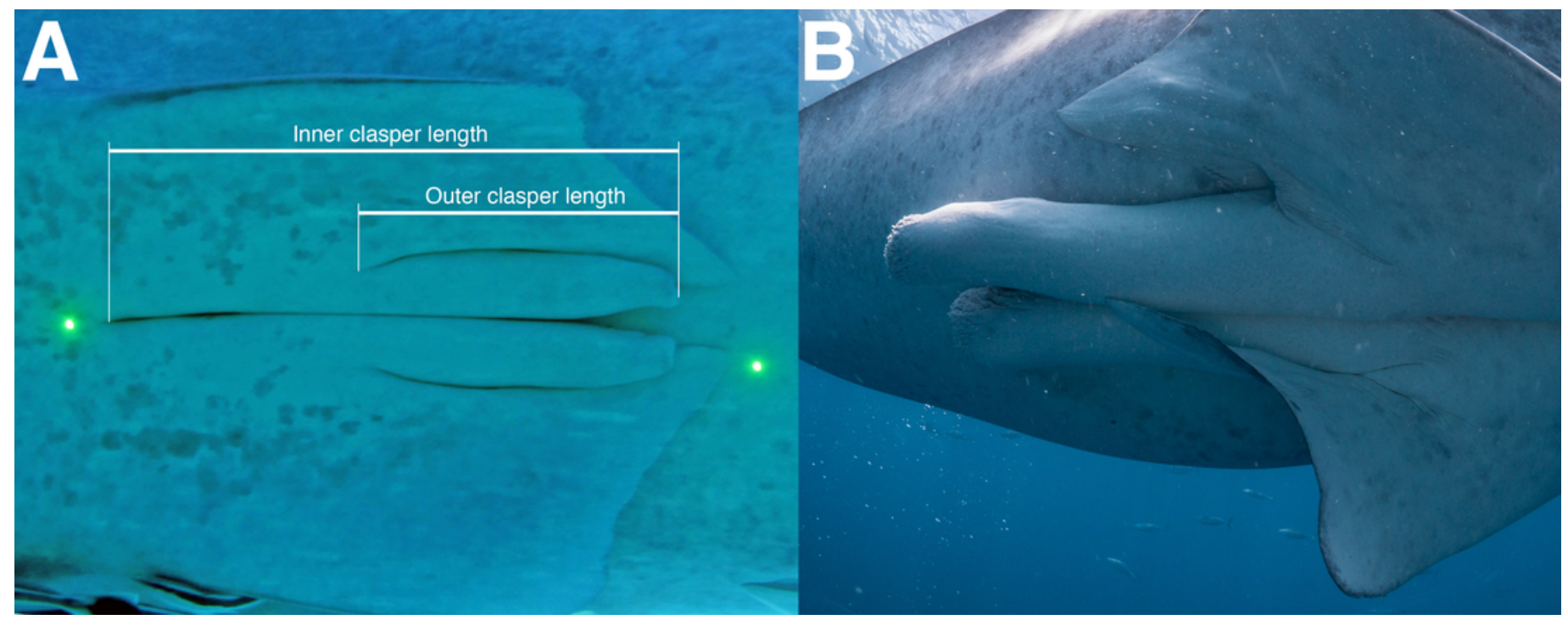


3

Numbers of whale sharks per size bin in Mozambique and Tanzania

Fig. 3 The number of whale sharks $($ red $=$ females, blue $=$ males) per size bin in $(A)$ Mozambique and (B) Tanzania. 
A
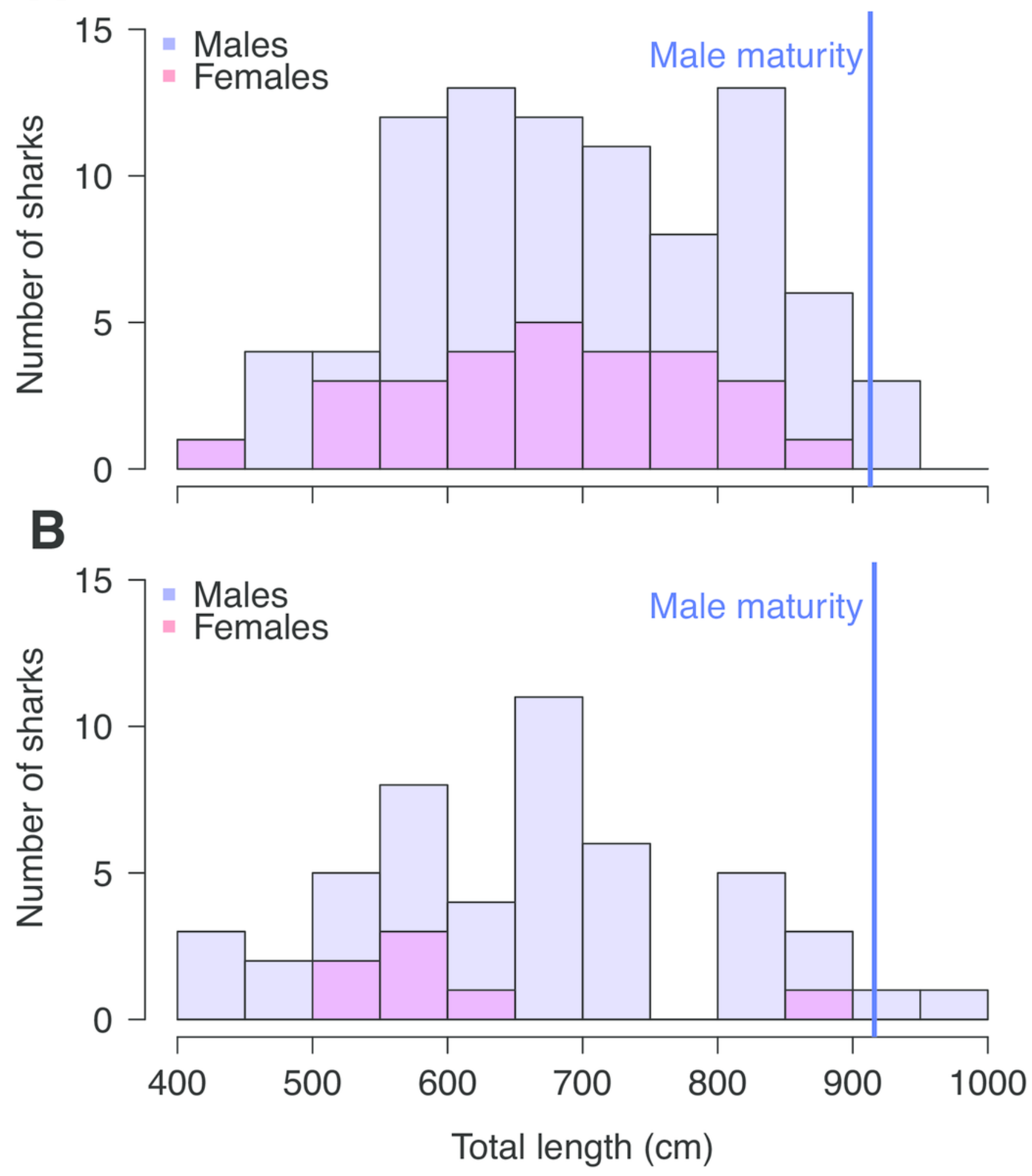
4

TL and CL for male whale sharks

Fig. 4 Total length and inner clasper length of male whale sharks ( $\square=$ immature $\boldsymbol{\Delta}=$ mature) in Mozambique and South Africa (blue) and Tanzania (red).

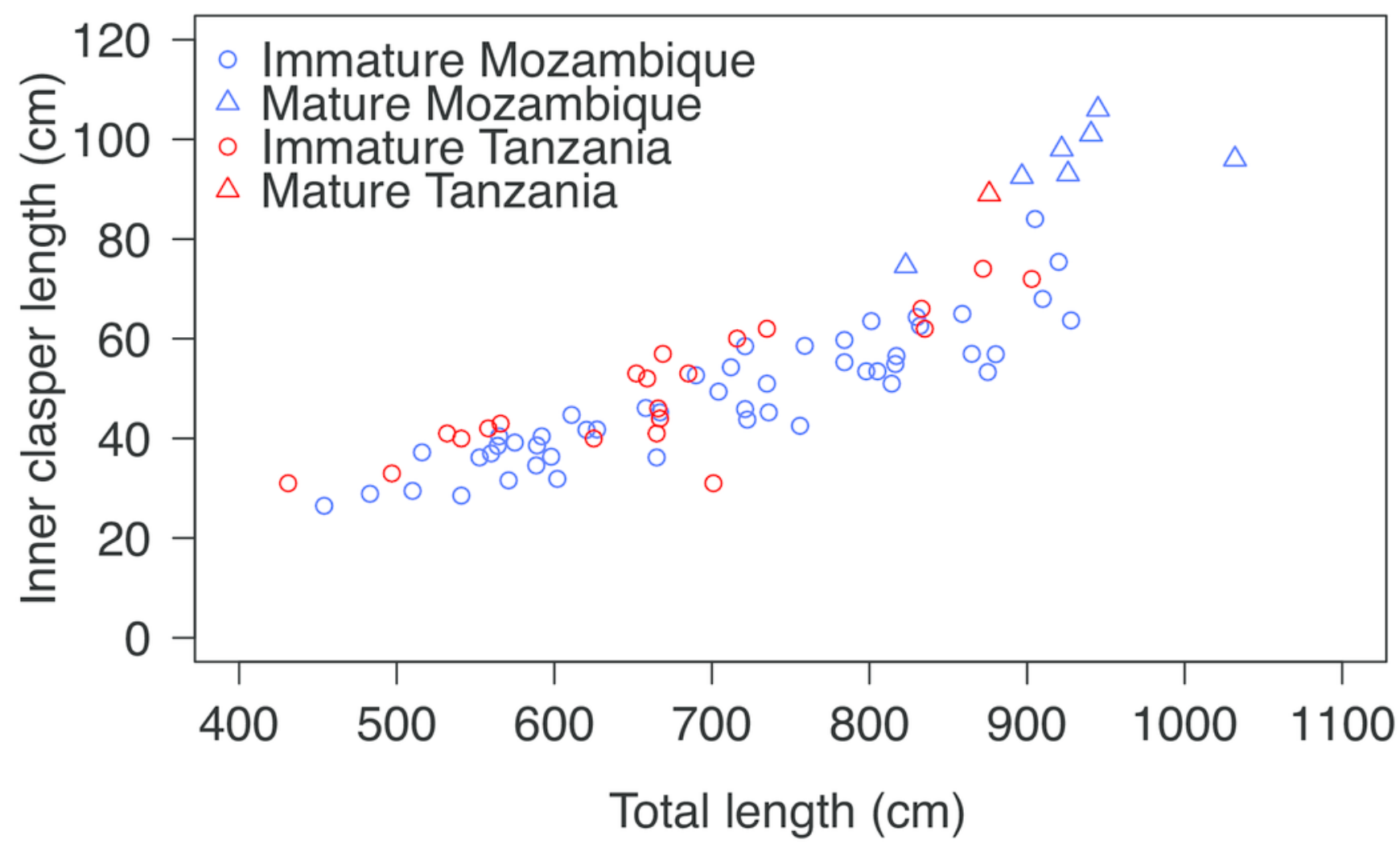




\section{5}

Total length and clasper length at maturity

Fig. 5 Binary logistic plot of maturity in male whale sharks against (A) total length, with $\mathrm{TL}_{50}$ $=916 \mathrm{~cm}$; and $(\mathrm{B})$ inner clasper length, with $\mathrm{CL}_{50}=81.0 \mathrm{~cm}$. 


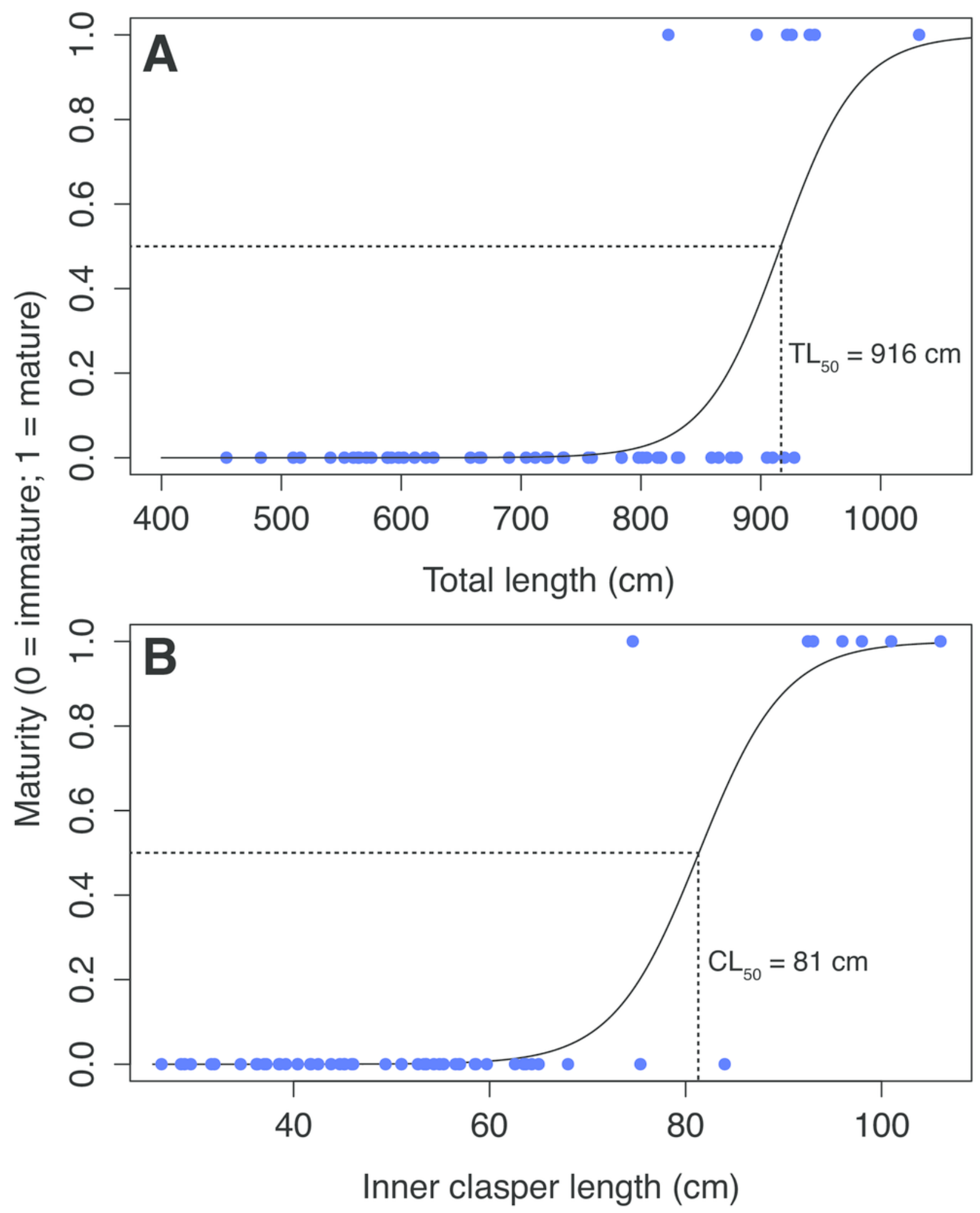


6

Growth increments

Fig. 6 Observed growth increments of male (black) and female (grey) whale sharks plotted as size at age based on back-calculated lengths from vertebral band pair counts (Wintner, 2000) with $95 \% \mathrm{Cl}$ indicated by dashed lines. The initial size measurement was placed on the $\mathrm{PCL} /$ band pair count regression (dark line).

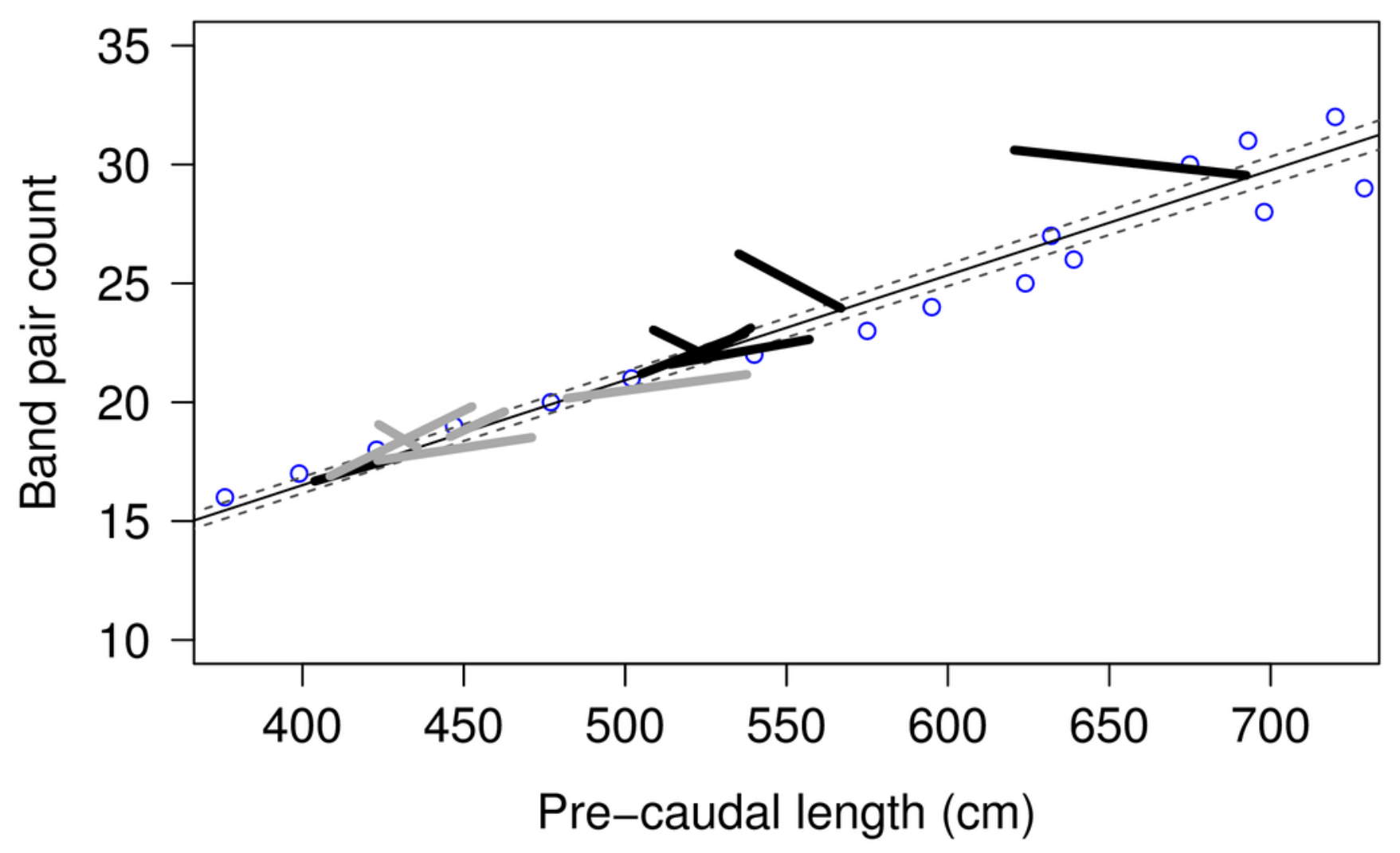


7

Comparisons of whale shark aggregation sites

Fig. 7 The population structure of whale shark aggregations around the world, with mean total length in red and length range in blue, plotted on the total length range for the species. References: 1 (this study), 2 (Beckley et al., 1997) , 3 (Rowat et al., 2011) , 4 (Brooks et al., 2010) , 5 (Berumen et al., 2014) , 6 (Riley et al., 2010) , 7 (Pravin, 2000) , 8 (Hobbs et al., 2009) , 9 (Norman \& Stevens, 2007) , 10 (Hsu et al., 2012) , 11 (Graham \& Roberts, 2007) , 12 (Ramírez-Macías et al., 2012a) , 13 (Fox et al., 2013) , 14 (Ramírez-Macías et al., 2012b) .

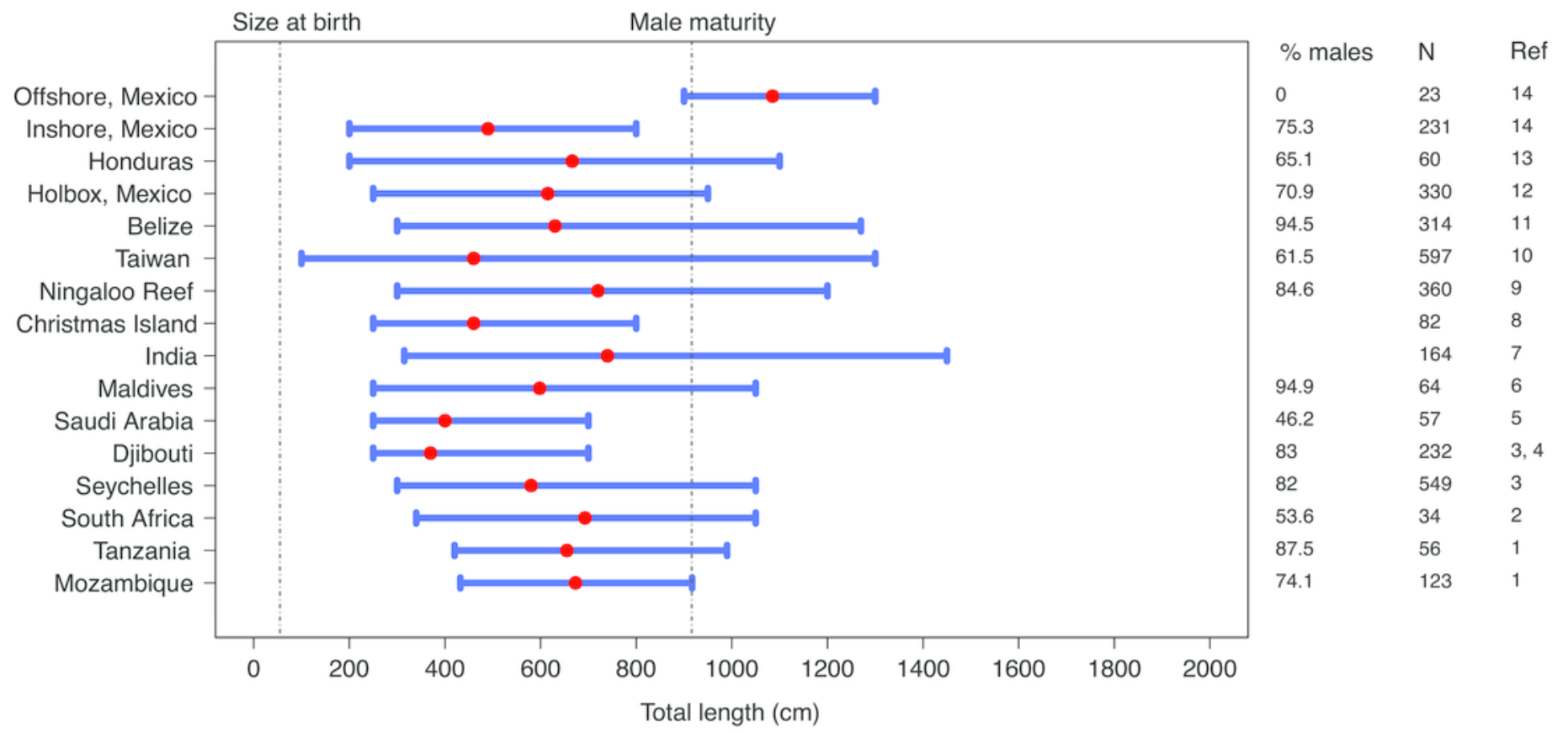


Table $\mathbf{1}$ (on next page)

Whale shark sizes in Mozambique and Tanzania

Table 1. The size of whale sharks measured with photogrammetry in Mozambique and Tanzania by sex, with male clasper measurements from South Africa included under Mozambique. 


\section{PeerJ Reviewing Manuscript}

\begin{tabular}{|c|c|c|c|c|c|c|}
\hline & \multicolumn{3}{|c|}{ Total length $(\mathrm{cm})$} & \multicolumn{3}{|c|}{ Clasper length $(\mathrm{cm})$} \\
\hline & $\mathrm{N}(\%)$ & Mean $( \pm \mathrm{SD})$ & Range & $\mathrm{N}$ & Mean $( \pm \mathrm{SD})$ & Range \\
\hline \multicolumn{7}{|c|}{ MOZAMBIQUE } \\
\hline Males & $87(75.7 \%)$ & $692( \pm 119)$ & $445-934$ & 57 & $54(20)$ & $27-106$ \\
\hline Females & $28(24.3 \%)$ & $670( \pm 108)$ & $439-858$ & & & \\
\hline Total & 123 & $684( \pm 118)$ & $439-934$ & & & \\
\hline \multicolumn{7}{|c|}{ TANZANIA } \\
\hline Males & $49(87.5 \%)$ & $660( \pm 131)$ & $420-990$ & 22 & $51(15)$ & $31-89$ \\
\hline Females & $7(12.5 \%)$ & $620( \pm 117)$ & $541-871$ & & & \\
\hline Total & 56 & $655( \pm 129)$ & $420-990$ & & & \\
\hline
\end{tabular}

